\title{
"Pòlemos Is Father to All Things": Elaborating and Enacting Conflict Through Theatre-Education
}

\author{
Claudia Chellini \\ Indire-National Institute for Documentation, Innovation and Educational Research \\ Giovanni Carli \\ University of Florence
}

\begin{abstract}
Since its debut theatre has brought conflict to the stage: with oneself, the other and the context. Theatre configures itself as a place that keeps away the background noises. It represents an instrument of authenticity, made up of acts and relationships, which are conveyed by a corporeality that involves in the daily school scene, typical scene of conflict mediation. Referring to experiences conducted in the last ten years, we highlight some pedagogical strategies to improve of relationships and to the personal development. Theatre face discomfort also through paralinguistic strategies and speeches providing tools to learn about and manage emotional states.
\end{abstract}

Keywords: theatre, conflict, education, theatre-education

\section{INTRODUCTION}

A conflictual and dynamic vision of reality has long formed one of the main undercurrents of Western philosophical reflection. This vision finds its fullest and most incisive expression in Heraclitus's description of pòlemos as "the most intimate and essential dimension of the human being, both in its relation to itself, and above all in its relation with all that which surrounds it, physically and socially" (Segreto, 2011, 14). The Greek term pòlemos stands for war, fought on the battlefield and connected with violence, the destruction and even the annihilation of the other; this kind of struggle is a metaphor for the essential law of reality (Bonetti, 1960), that from which all else is derived.

Today, after more than a thousand years, we more usually use the term 'conflict'. With its wider semantic field, this term is more suited to indicate a struggle that, regardless of its apparent virulence, may entail a vast range of solutions, including some that are not violent (Segreto, 2011).

This terminological shift has certainly allowed for the adoption of a perspective that goes beyond observing the pervasiveness of conflict, and which instead attempts to formulate means by which it can be managed: the mediation methods proposed by 'conflict management' models thus aim at finding adequate solutions to the conflicts that can arise within a family, in the workplace, between countries, or at school.

On the other hand, however, no longer using the word 'war' in this field of studies conceals the disquieting awareness expressed by Heraclitus, which we instead need to take into account if we are to at least attempt to answer the following question: what educational tools can be efficacious in preventing the spread of a language of hate? 
The awareness we are pointing towards is that conflict cannot be entirely avoided or eliminated: conflict is not only against another, but also - and perhaps especially - internal. Psychoanalysis sees in love and hate, co-present within human beings since birth, the manifestation of our reaction to bodily stimuli, be they pleasurable or painful; this reaction is linked to the attempt to incorporate that which provokes pleasure, and, on the contrary, expel that which causes pain (Freud, 1979). But not all that which provokes pain can be literally expelled, taken away from us. Hence, since our earliest development as children, we carry out a kind of symbolic expulsion: we see and reject in the other that which actually belongs to us (to our body, to our psyche). "The subject expels its 'worst' components in the other, outside of him/herself, in the other that is made into the enemy, an other that cannot be assimilated to any ideal representation of the self" (Recalcati, 2004, p. VIII). In other words, we hate in the other that which we recognise as our own but cannot accept because it questions our identity, or rather, our ideal conception of ourselves.

We are thus faced with a situation of perennial conflict, or of war as Heraclitus would have it, between different and contraposed parts, and between ourselves and others. These contrasts are inherent in being human: they cannot be definitively resolved, but rather are in need of constant mediation aimed at finding at least temporary solutions. These solutions can only be based on our knowledge of ourselves, and on the awareness that pòlemos resides within all of us.

Ziccardi (2016) has noted how, in recent years, verbal violence has spread beyond ideological contexts connected to racism, religious intolerance, and homophobia, and can arise within any kind of discourse, however pedestrian, such as on television, with regard to a celebrity's outfit, or to something we have bought. If this observation is to be believed, then we cannot ignore how hateful language is not just connected to communicational and relational issues, or with social disadvantage, as the Council of Europe would instead seem to suggest is the case (Keen \& Georgescu, 2017). Rather, we argue that hateful language is connected to the difficulty of managing the internal war whose clamour makes its way outwards thanks to the diffuse opportunities of self-expression, especially in anonymous form, created by the web.

In our view, within an educational setting an efficacious response to these dynamics must be based on a holistic approach, integrating attention to both the mind and the body, affect and rationality, behaviour and thought. This approach is characteristic of theatre, "an ancient tool of education, [...] that enables subjects to create, modulate, and remodel how they take part in existence" (Buccolo, Mongili, Tonon, 2012, p. 11). We use the expression theatre-education to indicate activities that take place at school with the aim of educating through theatre. This didactical tool derives its experiential practice from a range of different fields such as pedagogy, sociology, psychology, as well as the various performance arts; it "trains individuals to face reality with more confidence, helps them to understand the difficult social setting in which they live, and supports them in their growth.

Theatre can help rediscover the pleasure of action and of trying out different forms of communication, favouring an integrated development of all personality levels. In this sense, it constitutes an educational tool which can return its centrality to the human being in all of its physical and spiritual components" (Oliva, 2015, p. 15).

Theatre-education takes place in a workshop set up in such a way as to avoid the excesses typical of "supermodernity" (Augé, 2009): the time-frame is that of the here and now of stage action, space takes on the connotations of the imaginary, and engagement entails de-centring the self. The body becomes the protagonist. It is a place that favours a suspension of the flow of daily life, and thus helps to "shift one's gaze towards experience as it is lived, in order to understand what we are while we are feeling things" (Valbusa \& Mortari, 2017, p. 22). The workshop also encourages the emergence of internal conflict within a protected environment, thanks to the presence of a host that guides and moderates activity, and to the fact that the 'as if' of play allows one to detach oneself from one's emotions while simultaneously eliciting them.

Theatre allows for experimentation within and with the body of a chosen situation: it allows school students to act it out, perceive it in its organic form, perceptively and proprioceptively. It thus leads students towards gaining an understanding of a text or situation at a level that is different from the cognitive and intellectual, and based instead on the emotions provoked by the actions of the body. Representing an emotion through the staging of connected "physical actions" (Toporkov, 1998, p. 111) is a way of living 
(or re-living) them through one's body, not only so as to give life to a character, but also - and this is what interests us from an educational point of view - to gain an awareness of one's feelings, as well as the ability to name them. The rehearsals that lead to the final end-of-workshop recital, alongside the various dramatization exercises, also have the function of encouraging multiple experimentations with the same physical action and the emotion connected to it, within the context of the enacted behaviour of a character, which might be very different from how the student might conduct him/herself in an analogous situation. Through meta-reflexive activity, students are given new ways of thinking and acting on different behavioural strategies.

\section{CONFLICTS ON STAGE}

In what follows, we offer our reading - informed by the discussion above - of some instances of theatreeducation. The cases described below are drawn from workshops conducted by a theatre theatre educator with a long-standing collaboration with the class's main teacher. The theatre educator's role was to offer a series of preparatory and improvisational exercises, but above all to observe and listen to the emotional and bodily responses of the participants, in order to respond to them in the here and now through the focalisation of a conflict that could act as a trigger and could thus also provide the direction for successive work.

\section{Note on Methods}

From within a broader corpus of theatre-education workshop activities, carried out in Tuscany over the past 10 years ${ }^{2}$ - starting in the 2009/2010 school year - we have selected 15 examples from kindergartens and primary and lower secondary schools located in different areas and communities (See Table 1).

Data collection methods included observation through the compiling of a field-diary, from a given project's ideation phase to its final evaluation. The field-diary was divided into five sections: 1) general information regarding the association carrying out the workshops, as well as the school and class which made the request to participate; 2) the educational pact and project agreed upon and co-formulated by the theatre theatre educator and class teacher, and the detailed workshop plan; 3) a record of all occurrences during each workshop session, noting behaviours, shortcomings, and potentialities which occasionally led to adjustments being made to the educational project; 4) returns, i.e. the description of the outputs planned for the conclusion of the project (end-of-workshop recital, drawings, etc.); 5) the theatre educator's evaluation of the project in its entirety and with regard to each of the goals formulated in the educational project.

In this article, we will only cover some of these experiences. We will interpret them in light of a set of guiding questions aimed at reflecting on how theatre-education may provide an educational tool fit for facing issues linked to emotional illiteracy, defined as "the inability to recognize - that is, name and identify - the experiences that characterize one's emotional life, in all of its complexity (Valbusa \& Mortari, 2017, p. 35), by helping students gain awareness of their emotions and of how to express them: what conflict has been chosen and triggered? To what end? What has the class discovered as a group? In 5 cases out of 15, the students prepared a final recital; in 8 workshops, we used a literary text for reference (RLT - See Table 1), while in the other 7 the students were provided with ad-hoc situations that they were required to simulate (SS - See Table 1). 
TABLE 1

LIST OF THEATRE-EDUCATION WORKSHOPS

\begin{tabular}{|c|c|c|c|c|c|c|}
\hline $\begin{array}{c}\text { School } \\
\text { Year }\end{array}$ & Title & Ref. & $\begin{array}{l}\text { School } \\
\text { Grade }\end{array}$ & $\begin{array}{c}\text { Class } \\
\text { Year }\end{array}$ & Location & $\begin{array}{l}\text { Final } \\
\text { Recital }\end{array}$ \\
\hline $2009 / 2010$ & $\begin{array}{l}\text { Prometto che ti sposo } \\
\text { (I Promise I'll marry } \\
\text { you!) }\end{array}$ & $\begin{array}{l}\text { RLT } \\
\text { The } \\
\text { Betrothed } \\
\text { (Manzoni) }\end{array}$ & $\begin{array}{l}\text { Lower } \\
\text { secondary } \\
\text { School }\end{array}$ & III & $\begin{array}{l}\text { Sesto Fiorentino } \\
\text { (Florence-Italy) }\end{array}$ & Yes \\
\hline $2010 / 2011$ & Canti & $\begin{array}{c}\text { RLT } \\
\text { Divine } \\
\text { Comedy } \\
\text { (Dante } \\
\text { Alighieri) }\end{array}$ & $\begin{array}{l}\text { Lower } \\
\text { secondary } \\
\text { School }\end{array}$ & II & $\begin{array}{l}\text { Sesto Fiorentino } \\
\text { (Florence-Italy) }\end{array}$ & Yes \\
\hline $2011 / 2012$ & $\begin{array}{l}\text { Una storia nata in } \\
\text { classe } \\
\text { (A story born in the } \\
\text { classroom) }\end{array}$ & RLT & $\begin{array}{l}\text { Primary } \\
\text { School }\end{array}$ & II & $\begin{array}{l}\text { Sesto Fiorentino } \\
\text { (Florence-Italy) }\end{array}$ & Yes \\
\hline $2013 / 2014$ & Gulliver & RTL & Kindergarten & 3 years & $\begin{array}{l}\text { Sesto Fiorentino } \\
\text { (Florence-Italy) }\end{array}$ & No \\
\hline $2013 / 2014$ & $\begin{array}{l}\text { Senza Titolo } \\
\text { (untitled) }\end{array}$ & SS & $\begin{array}{l}\text { Lower } \\
\text { secondary } \\
\text { School }\end{array}$ & $\begin{array}{c}\text { all } \\
\text { classes } \\
3\end{array}$ & Carrara (Italy) & No \\
\hline $2014 / 2015$ & $\begin{array}{l}\text { La tribù dei Tabù } \\
\text { (Taboo tribe) }\end{array}$ & SS & $\begin{array}{l}\text { Lower } \\
\text { secondary } \\
\text { School }\end{array}$ & $\begin{array}{c}\text { all } \\
\text { classes } \\
3\end{array}$ & Carrara (Italy) & No \\
\hline $2014 / 2015$ & $\begin{array}{l}\text { Tutti per uno } \\
\text { (All for one) }\end{array}$ & SS & $\begin{array}{l}\text { Lower } \\
\text { secondary } \\
\text { School }\end{array}$ & I & Carrara (Italy) & No \\
\hline $2014 / 2015$ & $\begin{array}{l}\text { Emozioni } \\
\text { (Emotions) }\end{array}$ & SS & $\begin{array}{l}\text { Lower } \\
\text { secondary } \\
\text { School }\end{array}$ & II & Carrara (Italy) & No \\
\hline $2014 / 2015$ & $\begin{array}{l}\text { Il cantiere delle } \\
\text { differenze } \\
\text { (The dockyard of } \\
\text { differences) }\end{array}$ & SS & $\begin{array}{l}\text { Lower } \\
\text { secondary } \\
\text { School }\end{array}$ & III & Carrara (Italy) & No \\
\hline $2015 / 2016$ & $\begin{array}{l}\text { Fiabe per bambini } \\
\text { (Fables for children) }\end{array}$ & RLT & $\begin{array}{l}\text { Lower } \\
\text { secondary } \\
\text { School }\end{array}$ & II & Carrara (Italy) & No \\
\hline $2015 / 2016$ & $\begin{array}{l}\text { Il baule viaggiante } \\
\text { (The travelling } \\
\text { suitcase) }\end{array}$ & RLT & $\begin{array}{l}\text { Primary } \\
\text { School }\end{array}$ & $\begin{array}{c}\text { all } \\
\text { classes } \\
3\end{array}$ & $\begin{array}{c}\text { Pontassieve/Floren } \\
\text { ce (Italy) }\end{array}$ & No \\
\hline
\end{tabular}




\begin{tabular}{|c|c|c|c|c|c|c|}
\hline $2015 / 2016$ & $\begin{array}{l}\text { Il baule viaggiante } \\
\text { (The travelling } \\
\text { suitcase) }\end{array}$ & RLT & $\begin{array}{l}\text { Lower } \\
\text { secondary } \\
\text { School }\end{array}$ & $\begin{array}{c}\text { all } \\
\text { classes } \\
3\end{array}$ & $\begin{array}{c}\text { Rignano } \\
\text { sull'Arno/Florence } \\
\text { (Italy) }\end{array}$ & No \\
\hline $2016 / 2017$ & Green Eggs and Ham & RTL & $\begin{array}{l}\text { Primary } \\
\text { School }\end{array}$ & III & Florence (Italy) & No \\
\hline $2018 / 2019$ & $\begin{array}{c}\text { Il Paese delle Piume e } \\
\text { delle Pietre } \\
\text { (The country of } \\
\text { feathers and stones) }\end{array}$ & SS & $\begin{array}{l}\text { Primary } \\
\text { School }\end{array}$ & $\begin{array}{c}\text { all } \\
\text { classes } \\
3\end{array}$ & $\begin{array}{c}\text { Pavana/Pistoia } \\
\text { (Italy) }\end{array}$ & Yes \\
\hline $2018 / 2019$ & $\begin{array}{l}\text { [Io] Attraverso il } \\
\text { bosco delle emozioni } \\
\text { ([I go] Through the } \\
\text { forest of emotions) }\end{array}$ & SS & $\begin{array}{c}\text { Primary } \\
\text { School }\end{array}$ & II & $\begin{array}{l}\text { Montale/Pistoia } \\
\text { (Italy) }\end{array}$ & Yes \\
\hline
\end{tabular}

\section{Literary Conflict}

In those cases where the conflictual material on which to work was furnished by a literary text, the theatre educator, together with the class teacher, chose - on the basis of the educational project - a set of episodes that were subsequently performed and laid out in a plot. The class was then provided with games and improvisational exercises: on the one hand, these were useful in familiarising the students with the theme of emotions, thanks to a bodily experience that allowed for the emergence of their feelings and of how and when they expressed them; on the other hand, these exercises were also useful in defining the final structure of the text that was then turned into a script for the recital. There were two exceptions to this pattern among the cases we discuss here: first, workshops carried out in a kindergarten setting, where the creation of a script is impossible, and second, the Fables for children project, whose planned output comprised the re-writing of a fable and its dramatization within the workshop.

The text of the project titled I promise I'll marry you! directed at lower secondary school students (ages 11-13), included narrated sections, and scene that represented some of the main conflictual nodes of Manzoni's The Betrothed. The choice of episodes aimed to provoke an awareness of the emotions that can emerge from a situation of conflict, and of the possible behavioural reactions to it.

For example, let is look at what happened during the preparation of the scene in which Fra' Cristoforo enters Don Rodrigo's dining hall to try to convince him to let Renzo and Lucia marry. Prior to the dialogue between the scene's two protagonists, we had inserted a new element with the aim of drawing out the theme of violence as a relational mode typical of the powerful against the weak, which is central to Manzoni's work and still extremely relevant today. In this scene, Don Rodrigo ordered one of his henchmen to bring a chair for Fra' Cristoforo. In our improvisation, the henchman refused, claiming that Fra' Cristoforo was not a man of high enough rank. The student who was acting as Don Rodrigo stopped in his tracks, clearly surprised, not knowing how to continue. The theatre educator intervened as follows:

"Student: But if he [the henchman] isn't going [to bring the chair], what can I do about it, I mean, it's not like I can hit him!

Theatre educator: How do you think Don Rodrigo would react?

Student: Should I grab him by the throat?

Theatre educator: I don't know. How do you think Don Rodrigo would react?

Student: Really? OK, I get it.

Theatre educator: Watch out: the character can hurt others, but the actor mustn't." (Field diary, June 2010)

The student who was interpreting Don Rodrigo did the scene over, finally free to let his inhibited aggressiveness emerge in a safe setting: he physically forced the henchman to obey his order. This allowed 
the children to understand the relationship between the characters, and thus their personalities; this in turn allowed them to gain some insight about themselves and about others, and consequently, to understand the context, and with it, the text itself.

The student's bodily reaction corresponds to the bodily nature of the emotion he felt: theatre furnished him with an opportunity to experiment with one his own traits. Responding to an ongoing follow up conversation on what remained, after ten years, of that theatre-education experience, the student who interpreted Don Rodrigo continues today to ponder his aggressive trait: "because I had to interpret a 'bad' character, like Don Rodrigo, while at the same time being a boy with a rather strong personality, it was hard for me to distinguish how much I was immersing myself in Don Rodrigo, and how much, instead, my Don Rodrigo was influenced by my own personality and mannerisms" (F.C., follow-up 2019).

Another project, in which a class of teenagers developed a recital based on a few chapters from Dante's Divine Comedy, also focussed on the body: the recital represented physically (for the actors) and visually (for the audience) the hindrances created by the hellish beings that the protagonist encounters on his path. In one scene, Dante - who different children took turns in interpreting - walked amidst the damned, who were lying on the ground squirming, wailing, and grabbing at his ankles; in this setting, the protagonist could only move with extreme difficulty, and found it equally difficult to speak with his accompanier, Virgil, whom he asked for information on the various characters who entered the scene. Some of these characters, crawling on the ground or unsteadily holding themselves up, would speak to Dante, but were in turn constantly shoved and pulled down by the others. Thus, the children's entire body was engaged in the scene, and once again, through the body they could understand the relationships and context of the scene, and more broadly the text in its entirety. The students were faced not only with difficulty in moving freely, but also with finding a way of expressing themselves with their voices, of hearing others, in a context saturated with the wails and cries of the damned.

The students were thus able to perceive the rage, violence, and frustration caused by any hindrances on our free and total expression, represented by the hellish beings of Dante's Inferno; and they were able to feel how much such hindrances could influence their behaviour and relationships with others, beyond the fiction of theatre. On the one hand, this meant that each child had to face his or her feelings and emotions, while the theatre educator guided them in analysing their emotional responses and in understanding their effects. On the other hand, it also allowed the students to traverse Dante's work, leading them to a wider and deeper understanding of the literary text.

The Gulliver project, drawn from Swift's novel Gulliver's Travels, involved kindergarteners. Its aim was to work on the children's perception of their body and of their body in motion. The project's starting point was a reading by the theatre educator of Gulliver's encounter with the Lilliputians, followed by the children's dramatized re-enactment of the story. First, the children impersonated the Lilliputians, tying up their teacher who acted as Gulliver. Then the roles were reversed, and each child became Gulliver and was tied up by the theatre educator and the teacher. Because Gulliver was impersonated by the teacher, an adult, while the children impersonated the Lilliputians tasked with tying him up, impersonating Gulliver meant impersonating an adult. The pleasure of acting - and feeling - like a giant, large and strong enough to break the threads that tied him up, was thus accompanied by an experience of role reversal which, while simplified, was useful in exercising a form of de-centring.

An occurrence which took place towards the end of the project is particularly relevant to the theme of this paper. The children built the village of Lilliput out of a set of small boxes - no taller than $20 \mathrm{~cm}$ - that represented the village's houses: while impersonating Gulliver, they were then tasked with walking around the village without destroying it. After some initial hesitancy, the children eventually leapt at the opportunity of finally being the big ones and lean into their aggressive drives, compensating their perception of their own weakness, without causing any real damage. The theatre educator thus led them to reflect on the difference between stomping down the little mock-houses, which would have prevented the other children from playing with them, and instead moving them with a kick, which would not have destroyed them and hence would have permitted the game to continue once the boxes had been put back in place. The children experienced the difference between venting their aggression without any restraints, and instead 
acting it out within a regulated environment. As well as being cathartic, then, the experience of theatre helped the children learn how to manage their drives in socially acceptable ways.

The final workshop we wish to discuss here is Fables for children - whose title was a provocation, as the workshop involved adolescents. The project focussed on working on the physicality of language and in particular of conflictual language. Inspired by the collective version method ${ }^{4}$, the workshop activity was based on the version of the popular fable Dauntless Little John published by the Grimm brothers and translated into Italian by Antonio Gramsci in his Prison Notebooks (1929). During the first session of the workshop, the theatre educator read the fable to the teenagers and then asked them to re-tell it by re-writing it, explaining to them that he would be the only person to read their papers and that they were free to use any kind of language they wished, including profanities. The theatre educator then created a script from the writings produced by the students, who then dramatized this collectively created story. The most interesting theme that emerged from this workshop concerned language. The epithet that the adolescents used most frequently in their stories to describe Little John's father - who threw his son out after accusing him of being a slacker - was "piece of shit" (stronzo). During the dramatization, the expression would provoke the typical embarrassed giggle produced by a profanity being uttered in a formal setting. We thus proceeded to reflect upon and analyse language. What equally meaningful but more socially acceptable synonym might have been used? What if language lacked such a term? What kind of performance should an actor produce on stage when uttering an excremental profanity? What emotion is connected to it? How might the same emotion be channelled by using different terms? The time we had at our disposal (10 hours) was not sufficient to bring the theatre play to its conclusion; but the project, which ended with the final question left open, nonetheless allowed the adolescents to experience the physicality of language, feel it in their bodies and think of it as a linguistic act (Searle, 1976) which carries consequences for those who listen as well as for those who speak.

\section{Playing Out Conflict Through Ad-Hoc Situations}

A different kind of workshop featured the creation of a project starting from a point of conflict which schools had identified as central to an unresolved classroom issue.

We chose two different approaches to this kind of workshop, in relation to the setting and available timeframe: in the first case, we worked on a pair of opposing concepts on the basis of which we built the material for the workshop and for the final recital; in the second, we used the typical forms of the Theatre of the Oppressed (Boal, 1994, 2005, 2011, Freire, 2011).

With regard to the former case, we first identified the terms comprising the two contrasting forms, such as solitary/gregarious, physical/reflexive, calm/angry, included/excluded. We then proceeded to turn the dichotomy into a metaphor, attributing a distinct quality to each of the terms: in the case of the project entitled The Country of Feathers and Stones, for example, we organized two groups, one comprised of Feathers - light, sociable, and living in a beautiful and easily accessible place - and the other comprised of Stones, heavy, isolated, and anti-social. The story centred on a potential conflict: the inhabitants of each of the countries have never met one another, when a party is announced; what will happen? The children expected the Feathers to go to the party in a merry and happy mood, and the Stones to be more litigious. Instead, the Feathers, caught up in the excitement of preparing for the event, bicker amongst themselves, letting their aggression emerge; the Stones, by contrast, display a curiosity that leads them to become more open towards others. The story has a happy ending, as the party leads to a friendship between the two countries based on accepting the other and oneself. Acting as Feathers and Stones, with their different and opposite physicality, the children experienced how serenity is not alternative to aggression, or anger to the pleasure of the encounter, but rather that in each of us there exists an inextricable complexity of feelings and emotions.

Starting with the 2013/2014 school year, the Untitled project began with a workshop on the techniques of the Theatre of the Oppressed, and was further developed over the course of the following year with four projects: The taboo tribe, The building site of difference, All for one, and Emotions.

These projects were carried out with lower secondary school classes (ages 11-13) whose teachers and school directors had registered issues of poor classroom integration and violence. The educational plans 
were thus focussed on the theme of bullying, within a wider relational framework linked to difference and inhibition.

Given that we only had two or three two-hour long sessions with each class, it was not possible to develop a gradual approach to the theme. Instead, we elected to simulate a number of appositely formulated situations which bore some similarity with real-life events that had occurred in the classroom. We were not looking to tackle the theme directly, but rather to elicit in the students a feeling for the physical tension of emotion, for their situational self-perception. The activity was articulated in three movements: 1) We conjured up a setting, such as a library. 2) We distributed roles at random; for example, A and B would be reading, and $\mathrm{C}$ would come in to disturb $\mathrm{A}$. We only provided an outline of each role, in order to let the behavioural strategies of each student emerge independently. 3) The theatre educator then let the action develop, and at the moment of highest tension, 4) he would intervene to interrupt it and replace the actors. Initially, because B had largely remained on the side-lines, only A and C were replaced, until B complained of not having been given an active role. The theatre educator pointed out to $\mathrm{B}$ that in that situation doing nothing meant being on the side of the disturber, and B then started playing the role actively and with selfawareness. 5) At this point, the theatre educator introduced another rigid rule: the students were allowed to use any kind language, and even a violent behaviour, but they absolutely had to stop when the theatre educator clapped his hands. The theatre educator explained that this would allow the students to feel the tension of their bodies at the precise moment of carrying out a violent action, whilst refraining from bringing it to completion. This led to the forum theatre phase (Capobianco \& Vittoria, 2012) of the activity: once the action had been stopped, the other participants were asked how they would have acted in the actors' place, and those who proposed alternative strategies were invited to replace them. In this way, each student was able to experience the consequences, risks, and advantages of their behavioural strategy, as well as to measure the discrepancy between what they said they would do and what they actually did. The students engaged with the game very quickly, and the role replacements allowed everyone to interpret both the bully and the victim, to feel in their bodies the tension of the emotion both of the role that was closest to their own lived experience, and of its opposite.

We would like to end this review by discussing the project titled (I go) Through the forest of emotions, which was carried out with primary school children and featured conflict at various levels. One level was connected to the difficult inclusion of a child with a disability, while a second level regarded the necessity of improving the relationship between the students from different second-year classes within the school. A third level was centred on the conflict that would be performed in the recital, which was structured so as to reflect the issues that the school needed to deal with. The recital told the story of a group of children who, like Hansel and Gretel, had been abandoned in the woods, and after various vicissitudes and having met the Great Wizard who lived in a hut in the forest, were able to return home and reach a happy ending. The story is framed in keeping with a classic conflict against the context (Stanislavskij, 1996): for the students, interpreting the children who had been abandoned in the woods meant identifying the physical action connected to a given affect (sadness, fear, rage, etc.), and overcome the inhibition against fully expressing what they felt (for example, no-one was able to credibly express joy in the same way they were instead able to do during free play). In this way, they could reflect on their behavioural strategies also through an exchange with others, both adults and their peers. This is the "magical if" (Stanislavksij, 2014), the imaginary setting comprised on behaviours and physical actions that lead to what Stanislavskij called the reliving of a really real emotion.

\section{CONCLUSION}

In the educational setting, then, theatre is a special place in which language and relationships are exposed in all of their complexity, resisting their reduction to a 'short message'. Being able to identify a conflict is extremely important in enabling students to inhabit a setting in which, thanks to on-stage play, they can act as themselves, naturally and completely. Physicality made emotion becomes the means by which to live a totalizing experience capable of blocking out all non-necessary information and noise. 
Hateful language is thus meta-reflected through concrete tasks and actions, becoming an instrument with which to understand that which instead is not background noise and confusion.

This is only possible if a pòlemos, a theatrical, narrative, and situational conflict, is present; only through the medium of drama (Heathcote, 1995), the acting out of a conflictual relation, can such a complete narration of the self be achieved. Theatre is a medium that makes it possible to see and experience the here and now; its temporal dimension is the present, its main and foundational peculiarity is that it is the most volatile of all art forms, and this has an extremely high intrinsic social value. Theatre is an encounter (Brook, 1998) - a polemical one - that is real rather than virtual, and which each time needs to be woven into the plot of a text.

Vehiculating emotions through behaviour is the central point of the workshops we reviewed above. Reflecting on hateful language and on tenuous, simplified, easy, or short relations always implies the possibility of producing an instrument capable of supporting teachers in listening to their students actively and empathetically, as people who are being formed (Rogers, 2013; Boffo, 2007).

Without doubt, the experience itself, rather than the final recital, is the main vessel for the transmission of the workshop's educational value to the participants. Nonetheless, we would argue that the recital, as a peak experience (Maslow, 1971) both emotionally and physically, constitutes the main cause of the eventual - and sought after - rooting of the experience in the participants' physical memory, restructuring their behaviours and views on the world, on others, and on themselves - in short, on what a relation is.

"I remember how I found it hard to approach theatre acting [... I felt intimidated by the audience and I wondered how some of my classmates managed to get through it $[\ldots]$.

With dedication and perseverance, the recital progressively took shape, and I remember that it was a great success. It certainly was a personal victory for me, and it taught me that sometimes it's necessary to leave one's comfort zone to explore something new.

I don't know if by coincidence, but that same year I began figure-skating and the year after I started doing shows." (M.Z., 2019 follow-up interview).

The recital, a risk and a fear that need to be met head on, offers a synthesis of the entire experience and helps it take root, fostering a key passage: from a cultural behaviour (what it is right to think) to a natural thought (what I think).

While it is true that in the setting of theatre-education the schools themselves require the final recital, often indulging the wishes of the children's families, we would argue that the final recital needs to be reconsidered as an important challenge that must be overcome. The recital simultaneously requires problemsolving and offers a concrete task that transversally engages multiple spheres: its domain is not included in any school subject, but instead interests, or rather interweaves them all. Theatre, in short, activates the difficulty-attention-motivation experiential chain (Cornoldi, 1995) which leads to what is often referred to in psychology as strong restructuring (Kuhn, 1969; 2000) or changes in practice (Kelly, Charlsen, Cunningham, 1993).

A conflict can be taken on or avoided (Elliot, 1999; Elliot \& Harackiewicz, 1996): by inserting the person within a narrative and fictional setting, theatre makes it possible to try out different strategies, from avoidance to strategic actions aimed at solving or studying the problem from multiple perspectives. In particular, theatre is an activity that allows for multiple re-narrations of the self. Faced with a singular starting narrative, tied up in the threads of a monolithic and fixed role, theatre opens up the possibility of finding and experiencing other behavioural and self-narrational strategies, new ways of seeing the world and one's relation with oneself and others, on the path towards an authentic open-mindedness.

As an educational approach, then, theatre-education is problem-based, or rather, we could say, conflictbased. Thanks to repetition, volatility, and to the setting it requires, it facilitates the discovery of other strategies alternative to hateful language, and opens new horizons of relational possibility. Theatreeducation emerges forcefully as a response to both hate-speech and misunderstanding. Theatre makes it possible to gain awareness, through an experience in the sense outlined by Dewey (2014), of a virtual world where hate is reified with ever more concrete consequences (politically, socially, etc.); but, by contrast, theatre also makes it possible to gain awareness of an imaginary world with equally concrete effects, which 
is instead the result of a path of personal growth and formation, a world of theatre which is founded on the interweaving of reality and fiction.

\section{ENDNOTES}

1. This definition was given by Stanislavskij during the latter phase of his career.

2. Giovanni Carli has worked as a professional theatre actor and instructor since 2003.

3. While the workshops were carried out in different schools, and not all classes in all schools participated, the workshops themselves involved students from all year groups.

4. The method, conceived by psychoanalyst Adalinda Gasparini, has attained important results not just with regard to aiding the development of children's expressive abilities, but also with regard to inclusion within the class-group, not least of children with various kinds of difficulties.

\section{REFERENCES}

Augé, M. (2009). Non luoghi, Milano: Elèuthera.

Boal, A. (1994). L'arcobaleno del desiderio. Manuale per la pratica del teatro dell'oppresso. Molfetta: La Meridiana.

Boal, A. (2005). Il poliziotto e la maschera. Giochi, esperienze e tecniche del teatro dell'oppresso. Molfetta: La Meridiana.

Boal, A. (2011). Il teatro degli oppressi. Teoria e tecnica del teatro. Molfetta: La Meridiana.

Boffo, V. (2007). Comunicare a scuola: autori e testi. Roma: Apogeo Editore.

Bonetti, A. (1960). La concezione dialettica della realtà in Eraclito. Rivista di Filosofia Neo-Scolastica, 52(2/3), 319-335.

Brook, P. (1998). Lo spazio vuoto. Roma: Bulzoni.

Buccolo, M., Mongili S., \& Tonon, E. (2012). Teatro e Formazione. Teorie e pratiche di Pedagogia teatrale nei contesti formativi. Milano: FrancoAngeli.

Capobianco, R., \& Vittoria, P. (2012). Dalla narrazione al teatro sociale: l'esperienza del teatro forum. Revista Querubim. Revista eletrônica de trabalhos científicos nas áreas de Letras, Ciências Humanas e Ciências Sociais, 8, 1-8.

Cornoldi, C. (1995). Metacognizione e apprendimento. Bologna: Il Mulino.

Dewey, J. (2014). Esperienza e educazione. Milano: Cortina Raffaello.

Elliot, A.J. (1999). Approach and avoidance motivation and achievement goals. Educational Psychologist, $34,169-189$.

Elliot, A.J., \& Harackiewicz, J.M. (1996). Approach and Avoidance Achievement Goals and Intrinsic Motivation: A Mediational Analysis. Journal of Personality and Social Psychology, 70(3), 461475.

Freire, P. (2011). La pedagogia degli oppressi. Torino: Gruppo Abele.

Freud, S. (1976). Pulsioni e loro destini, in Opere (Vol. VIII, pp. 13-35). Torino: Bollati Boringhieri.

Gasparini, A. (2007-2018). Psicoanalisi e favole - Scuola. Retrieved September 2019, from http://www.alaaddin.it/_VERSIONE_COLLETTIVA/index.html

Heathcote, D., \& Bolton, G. (1995). Drama for Learning: Dorothy Heathcote's Mantle of the Expert Approach to Education. Portsmouth: Heinemann Drama.

Keen, E., \& Georgescu, J. (2017). Bookmarks. Manuale per combattere i discorsi d'odio online attraverso l'educazione ai diritti umani. AICEM [Consiglio d'Europa 2014].

Kelly, G.J., Carlsen, W.S., \& Cunningham, C.M. (1993). Science education in sociocultural context: Perspectives from the sociology of science. Science Education, 77(2), 207-220.

Kuhn, D. (2000). Metacognitive development. Current Directions in Psychological Sciences, 9(5), 178181.

Kuhn, T.S. (1969). La struttura delle rivoluzioni scientifiche. Torino: Giulio Einaudi.

Maslow, A. (1971). Verso una psicologia dell'essere. Roma: Astrolabio-Ubaldini. 
Oliva, G. (2015). Il teatro come strumento di formazione umana nello sviluppo della creatività e della crescita personale. Scienze e Ricerche, 10, 15-21.

Recalcati, M. (2004). Sull'odio. Milano, Mondadori.

Rogers, C.R. (2013). La terapia centrata sul cliente. Firenze: Giunti.

Searle, J.R. (1976). Atti linguistici. Saggio di filosofia del linguaggio. Torino: Boringhieri.

Segreto, V. (2011). "Il padre di tutte le cose». Appunti per una pedagogia del conflitto. Milano-Udine: Mimesis Edizioni.

Stanislavskij, K.S. (1996). Il lavoro dell'attore su se stesso. Roma-Bari: Laterza.

Stanislavskij, K.S. (2014). Il lavoro dell'attore sul personaggio. Roma-Bari: Laterza.

Toporkov, V.O. (1998). Stanislavskij alle prove, gli ultimi anni. Roma: Ubulibri.

Valbusa, F., \& Mortari, L. (2017). L'orto delle emozioni. Teoria e ricerca sull'educazione alla vita affettiva. Milano: FrancoAngeli.

Ziccardi, G. (2016). L'odio online. Violenza verbale e ossessioni in rete. Milano: Raffaello Cortina Editore.

186 Journal of Higher Education Theory and Practice Vol. 20(15) 2020 